\title{
Biogas Upgrading Using Ash from Combustion of Wood Fuels: Laboratory Experiments
}

\author{
Johan Andersson ${ }^{1} \&$ Åke Nordberg ${ }^{2}$ \\ ${ }^{1}$ Research Institutes of Sweden (RISE) Agrifood and Bioscience, Uppsala, Sweden \\ ${ }^{2}$ Department of Energy and Technology, Swedish University of Agricultural Sciences (SLU), Uppsala, Sweden \\ Correspondence: Åke Nordberg, Department of Energy and Technology, Swedish University of Agricultural \\ Sciences (SLU), P.O. Box 7032, SE-750 07 Uppsala, Sweden. Tel: 4618-671-882.E-mail: ake.nordberg@slu.se
}

Received: April 20, 2017

Accepted: May 11, 2017

Online Published: May 29, 2017

doi:10.5539/eer.v7n1p38

URL: https://doi.org/10.5539/eer.v7n1p38

The research is financed by the Swedish Farmers' Foundation for Agricultural Research.

\begin{abstract}
The value of biogas produced at small scale facilities, such as farm scale biogas plants, can increase by upgrading it to vehicle fuel quality. However, commercial upgrading technologies available today are very costly for small scale applications. Ash from combustion of wood fuels has a high content of $\mathrm{Ca}$, which indicates favourable conditions for a high $\mathrm{CO}_{2}$ uptake capacity from biogas. The objective of this study was to assess the $\mathrm{CO}_{2}$ uptake capacity of ash from combusted wood pellets and wood chips in a laboratory scale solid bed reactor using an inlet gas mixture of $\mathrm{CO}_{2}$ and $\mathrm{CH}_{4}$ with the aim to reach $>97 \% \mathrm{CH}_{4}$ in the outlet gas. A gas with a defined composition of $65 \% \mathrm{CH}_{4}$ and $35 \% \mathrm{CO}_{2}$ was passed through a moisturised solid ash bed in an up-flow manner. The gas quality in the outlet gas and the $\mathrm{CO}_{2}$ uptake capacity of the ash was assessed. Bottom ash from combusted wood pellets showed the best uptake capacity of $0.20 \mathrm{~g} \mathrm{CO}_{2} / \mathrm{g}$ dry ash, which is 4-8 higher than studies where municipal solid waste incineration bottom ash was tested. The outlet gas from the ash reactor contained high concentrations of methane (up to $99.6 \%$ ) and the gas contained no $\mathrm{CO}_{2}$ until $\mathrm{CO}_{2}$ breakthrough occurred in the ash bed. Furthermore, the $\mathrm{pH}$ of the ash was reduced by 2 to 3 units due to the carbonation, which improves the prerequisites for recycling the ash to forestry. It was concluded that an ash bed with $\mathrm{Ca}$ rich wood ash has the ability to reach vehicle fuel quality regarding $\mathrm{CH}_{4}$ concentration. Based on the results, a biogas plant of $1 \mathrm{GWh}(3.6 \mathrm{TJ})$ per year would require approx. 650 tonnes of dry wood ash a year with an uptake of $0.20 \mathrm{~g} \mathrm{CO}_{2} / \mathrm{g}$ dry ash and an inlet biogas composition of $60 \% \mathrm{CH}_{4}$ and $40 \% \mathrm{CO}_{2}$.
\end{abstract}

Keywords: biogas upgrading, carbon dioxide, methane, wood ash, accelerated carbonation, laboratory scale

\section{Introduction}

Anaerobic digestion (AD) of biogenic material generates biogas and a nutrient rich digestate, which offers several benefits for the agricultural sector and society. Biogas contains methane $\left(\mathrm{CH}_{4} ; 50-70 \%\right)$, carbon dioxide $\left(\mathrm{CO}_{2} ; 30-50 \%\right)$ and trace gases such as hydrogen sulphide $\left(\mathrm{H}_{2} \mathrm{~S}\right)$. The $\mathrm{CH}_{4}$ in biogas can be exploited as a renewable energy source for production of heat and electricity, or for use as a vehicle fuel (Awe et al., 2017). Furthermore, greenhouse gas emissions are reduced due to replacement of fossil fuels, and in the case of anaerobic digestion of manure, also due to the avoidance of $\mathrm{CH}_{4}$ emissions from manure storage (Börjesson et al., 2010; Kimming et al., 2015). Biogas is conventionally used for combined heat and power (CHP) production at farm scale plants. However, the value of the heat generated is usually limited due to a reduced need for heat during the summer, and due to heat often can be produced at a lower cost with solid biofuels, such as wood pellets and wood chips (Lantz, 2012).

Another utilisation option is to upgrade the biogas to vehicle fuel quality or natural gas injection, i.e. increase the $\mathrm{CH}_{4}$ concentration and energy density of the gas by removing $\mathrm{CO}_{2}$. Commercially available technologies commonly used today include water scrubbing, amine scrubbing, pressure swing adsorption (PSA) and gas separation membranes (Bauer et al., 2013). Upgrading of biogas to vehicle fuel quality at farm scale could increase the value of the biogas, either for use on the farm (i.e. for tractors and machinery) or for external use (i.e. selling to the market). However, current costs for conventional upgrading technologies are too high to justify 
investments at the low biogas flows obtained from farm scale biogas production (Bauer et al., 2013). To reduce this cost, novel, simple, cost and energy efficient $\mathrm{CO}_{2}$ removal systems are required.

The use of bottom ash from municipal solid waste incineration (MSWI) for capturing $\mathrm{CO}_{2}$ from landfill gas or biogas has been investigated in several studies (Mostbauer et al., 2008; Mostbauer et al., 2014; del Valle-Zermeño et al., 2015). Capturing of $\mathrm{CO}_{2}$ is based on the principle of accelerated carbonation of ash, i.e. calcium oxide $(\mathrm{CaO})$ in the presence of moisture reacts with $\mathrm{CO}_{2}$ from flowing gas to form solid calcium carbonate $\left(\mathrm{CaCO}_{3}\right)$. Furthermore, the use of air pollution control (APC) residues from waste incineration has been demonstrated in a process called alkali absorption with regeneration (AwR), where $\mathrm{CO}_{2}$ is removed from landfill gas as it passes an alkali $(\mathrm{NaOH}$ or $\mathrm{KOH})$ solution. The spent solution, containing captured $\mathrm{CO}_{2}$ as $\mathrm{Na}_{2} \mathrm{CO}_{3}$ or $\mathrm{K}_{2} \mathrm{CO}_{3}$, is regenerated through reaction with $\mathrm{Ca}(\mathrm{OH})_{2}$ in moisturised $\mathrm{APC}$ to yield solid $\mathrm{CaCO}_{3}$ in the APC (Baciocchi et al., 2013a; Baciocchi et al., 2013b; Lombardi et al., 2015). Besides removing $\mathrm{CO}_{2}$ from the biogas and achieving a $\mathrm{CH}_{4}$ concentration of up to $99 \%$ in dry gas (Mostbauer et al., 2014), the environmental benefits of using incineration residues also includes stable storage of $\mathrm{CO}_{2}$ and reduced leakage of heavy metals from the ash (Starr et al., 2012; Starr et al., 2014).

Ash from combustion of wood fuels has a higher $\mathrm{CaO}$ content than ashes from MSWI bottom ash (Strömberg \& Herstad Svärd, 2012). This indicates favourable conditions to achieve high uptake of $\mathrm{CO}_{2}$ from biogas (Chavez \& Gudarrama, 2015). However, to the authors' knowledge the capacity and the performance of ashes from combustion of wood fuels for $\mathrm{CO}_{2}$ removal have not been reported in scientific literature before. In Sweden, 23\% of the total energy supply comes from bioenergy where wood fuels play an important role (Swedish Energy Agency, 2014). In 2012, the ash generated from solid wood fuels in Sweden was 255,300 tonnes total solids (TS), of which the major part was used as construction material at landfills, and only $18 \%$ was returned to forests as fertilizer (SCB, 2012). Thus, studies regarding the $\mathrm{CO}_{2}$ uptake capacity and performance for upgrading of biogas can be motivated based on the large amount of ash generated from wood fuels.

The objective of the present study was to assess the $\mathrm{CO}_{2}$ uptake capacity of ash from combusted wood fuels in a laboratory scale fixed bed reactor using an inlet gas mixture of $\mathrm{CO}_{2}$ and $\mathrm{CH}_{4}$. The aim was to reach vehicle fuel quality (> $97 \% \mathrm{CH}_{4}$ concentration) in the upgraded gas.

\section{Methodology}

\subsection{Ash}

Ash from combustion of wood pellets and wood chips were used for the experiments. Dry bottom ash from combusted wood pellets was collected directly from a $100 \mathrm{~kW}$ boiler (D’Allesandro) situated at Sätra Brunn, Sala Heby Energi, Sweden. A mixture of bottom and fly ash from combusted wood chips at three boilers with a total capacity of 1,000 kW (REKA) situated at Kungsängen, SLU, Uppsala, Sweden, was taken from an outdoor collection container exposed to some moisture. Once collected, the ashes were stored indoors in sealed vessels. The ashes contained only a few sintered particles (>10 $\mathrm{mm}$ in diameter), which were removed before the ash analyses and the carbonation experiments.

\subsection{Particle Size Distribution Of Ashes}

The wood chip ash (WCA) and the wood pellet ash (WPA) were sieved after drying $\left(105^{\circ} \mathrm{C}, 24 \mathrm{~h}\right) .50 .0 \mathrm{~g}$ of each ash was sieved by using a sieve shaker (Retsch KG type 3D) operated for five minutes with seven test sieves $(2.0 ; 1.4 ; 1.0 ; 0.63 ; 0.4 ; 0.2$ and $0.1 \mathrm{~mm})$. The different fractions obtained were weighted on an analytical balance (Mettler Toledo PB1502-S FACT).

\subsection{Experimental Set-Up}

The gas used in the experiments had a defined composition of $65 \% \mathrm{CH}_{4}$ and $35 \% \mathrm{CO}_{2}$, representing a common relation between $\mathrm{CH}_{4}$ and $\mathrm{CO}_{2}$ in manure based anaerobic digestion. The gas mixture was provided from a pressurised gas cylinder (AGA) placed on a balance (VETEK VB2-100-10) to measure weight loss of gas during operation. The gas flow rate was adjusted with a pressure regulator, and a gas meter (RITTER TG05) recorded the cumulative volume of gas entering the ash reactor (Figure 1). The gas passed through a water seal after the gas flow meter and before entering the bottom of the ash reactor. The gas tight cylinder-shaped ash reactor had a glass jacket (isolated with $14 \mathrm{~mm}$ Armaflex®), a lid, a plastic bottom, and a total volume of $20 \mathrm{dm}^{3}$ (height 0.3 $\mathrm{m}$; inner diameter $0.3 \mathrm{~m}$ ). The reactor was filled with ca $12 \mathrm{dm}^{3}$ water-adjusted ash before the experiments started, resulting in an ash bed height of ca $0.2 \mathrm{~m}$. The ash bed rested on a coarse mesh placed $5 \mathrm{~cm}$ from the bottom and covered by a nylon wire screen to retain the ash particles. The gas passed through the ash bed and out through the lid, and subsequently through a water seal before gas quality monitoring and evacuation to a fume hood. The temperature in the ash reactor and in the inlet and outlet gas was monitored. A simple pressure 
security valve consisting of a water seal $(14 \mathrm{~cm})$, also for estimating the pressure drop during operation, was placed in the bottom of the ash reactor and connected with tubing to the fume hood. During the 2 -step experiments, two reactors were coupled, i.e. the outlet gas from the first reactor was led to the inlet of the second reactor (Figure 1).

The ashes were carefully mixed with water in a trough to create a determined ratio of water and dry ash (L/S), before loading into the ash reactor. After sealing the reactor, the gas flow was started, ranging from 1.7 to 3.9 $\mathrm{dm}^{3} / \mathrm{h} / \mathrm{kg}$ moist ash (Table 1). The carbonation tests comprised of four 1-step and two 2-step experiments, as summarised in Table 1Three one-step experiments were conducted with WPA (no. 1-3). Experiment no. 2 was conducted on the carbonised ash from experiment no. 1 after it had been weighed out, mixed and sampled. Experiment no. 3 was performed at the same L/S-ratio (0.4) as experiment no. 1, but with a higher specific gas flow. The 2-step experiment with WPA was performed with the ash reactor from experiment no. 3, which was used as the first step (reactor 4A). This reactor was connected to the second ash reactor which was loaded with fresh ash (reactor 4B). One 1-step experiment (experiment no. 5) was performed with WCA, and that reactor was subsequently used as the first step in the 2-step experiment with WCA (experiment no. 6), see Table 1.

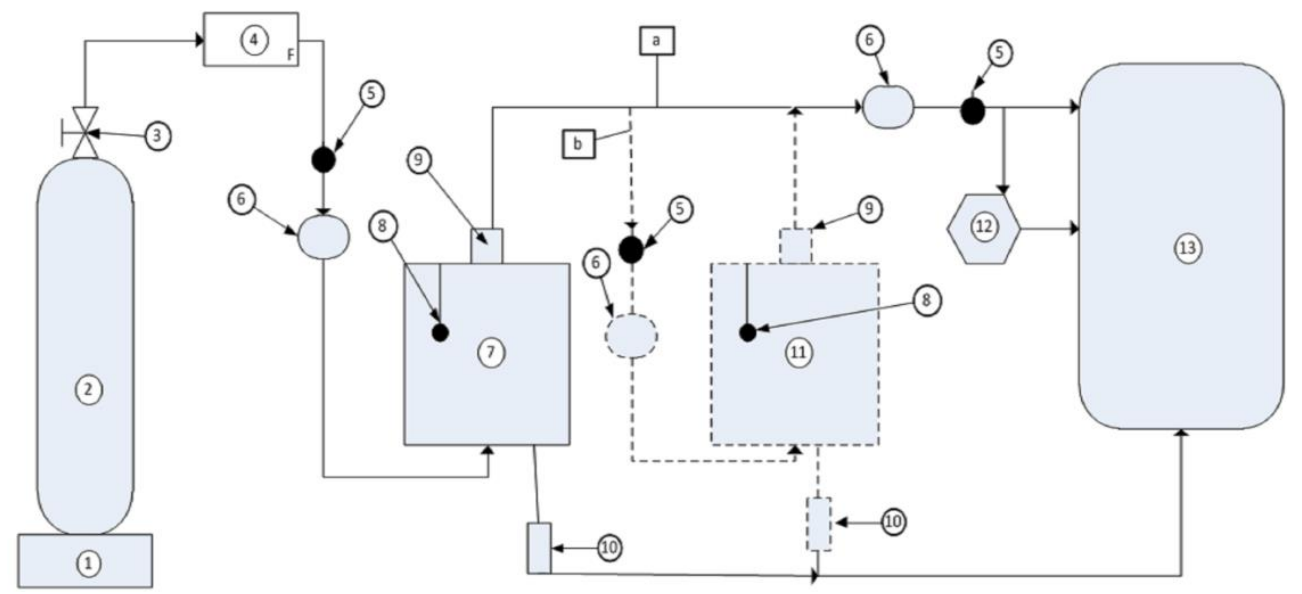

Figure 1. Experimental set-up. (1) Scale; (2) Gas cylinder; (3) Gas flow regulator; (4) gas flow meter; (5) thermometer; (6) water seal; (7) $1^{\text {st }}$ ash reactor; (8) Thermometer; (9) gas sampling point for GC; (10) security valve; (11) $2^{\text {nd }}$ ash reactor for 2 -step experiments; (12) gas analyser; (13) fume hood. The gas flow during the

1 -step experiments (a) bypassed the $2^{\text {nd }}$ ash reactor and the dashed lines (b) illustrate the gas flow and the additional equipment used for the 2-step experiments

\subsection{Analytical Methods}

Chemical composition of the ash was analysed after fusion with lithium metaborate, followed by dissolution in dilute nitric acid and atomic absorption spectroscopy (ASTM D3682, ALS Scandinavia AB, Luleå, analytical package MG2 AM). Total solids (TS) were determined according to Swedish Standards (SS 0281 13) and loss on ignition (LOI) at $1,000^{\circ} \mathrm{C}$.

The gas composition $\left(\mathrm{CH}_{4}, \mathrm{CO}_{2}\right.$ and $\left.\mathrm{O}_{2}\right)$ of the outlet gas from the ash reactor was determined with an infra-red gas analyser (GA2000, Geotechnical Instruments). Furthermore, the outlet gas was sampled for $\mathrm{CH}_{4}$ by gas chromatography as described by Westerholm et al. (2010), and $\mathrm{CO}_{2}$ concentration was measured using a saccharometer filled with $7 \mathrm{M} \mathrm{NaOH}$ according to Jarvis et al. (1995). The gas composition analyses were logged manually 7-14 times/day, mainly during the daytime.

The fresh ash and carbonised ash $\left(0.5 \mathrm{~g}\right.$ ash and $10 \mathrm{~g}$ distilled water) were titrated with $10 \mathrm{~N} \mathrm{H}_{2} \mathrm{SO}_{4}$ to $\mathrm{pH}<4.5$ to determine the buffering capacity. The $\mathrm{pH}$ was measured using a pH-meter (Jenway Model 3510).

\subsection{Calculations}

The measured inlet gas flow was reported at $1 \mathrm{~atm}(101.3 \mathrm{kPa})$ and $20{ }^{\circ} \mathrm{C}$. The $\mathrm{CO}_{2}$ uptake was determined by means of the mass balance of entering and exiting $\mathrm{CO}_{2}$ in the gaseous stream. The outlet gas volume was estimated by assuming that the volume of $\mathrm{CH}_{4}$ entering and leaving the ash reactor was the same because $\mathrm{CH}_{4}$ 
does not interact with compounds in the ash. In addition, the mass reduction of the gas cylinders total weight was used to compare the mass flow calculated by volumetric flow. The temperature and the gas concentrations of the inlet and outlet gas were measured and the results were used together with the registered gas volume to determine $\mathrm{CO}_{2}$ mass balance.

\section{Results}

\subsection{Chemical Composition and Characteristics of the Ashes}

WPA had the highest content of dry solids $(99.5 \%)$ because it was stored indoors, while WCA $(89.4 \%$ TS) was collected from an outside container exposed to moisture (Table 2). The LOI was higher for WCA, indicating a higher fraction of $\mathrm{CaCO}_{3}$ and $\mathrm{Ca}(\mathrm{OH})_{2}$ or residual organic carbon in the ash. The density of the WCA was slightly higher compared to WPA, which can partly be explained by the higher water content in WCA. The analysis of major mineral composition presented in Table 2 was performed after fusion with lithium metaborate and is reported as mineral oxides. This means for example that all calcium $(\mathrm{Ca})$ present in the analysed ash (as $\mathrm{CaCO}_{3}$, calcium silicates, $\mathrm{Ca}(\mathrm{OH})_{2}$, etc.) is reported as $\mathrm{CaO}$. The relative high portion of $\mathrm{Ca}$ in both ashes indicates a high potential to capture $\mathrm{CO}_{2}$.

Table 1. Overview of the carbonation experiments performed (WPA= wood pellet ash; WCA = wood chip ash)

\begin{tabular}{|c|c|c|c|c|c|c|c|c|c|}
\hline \multirow{2}{*}{$\begin{array}{l}\text { Exp no. } \\
\text { Ash }\end{array}$} & & 1 & 2 & 3 & $4 \mathrm{~A}$ & 4B & 5 & $6 \mathrm{~A}$ & $6 \mathrm{~B}$ \\
\hline & & \multicolumn{5}{|l|}{ WPA } & & WCA & \\
\hline \multirow[t]{2}{*}{ Exp. description } & & & 1-step & & \multicolumn{2}{|c|}{ 2-step } & 1-step & \multicolumn{2}{|c|}{ 2-step } \\
\hline & & fresh ash & $\begin{array}{l}\text { no1 } \\
\text { mixed }\end{array}$ & $\begin{array}{l}\text { fresh } \\
\text { ash }\end{array}$ & $\begin{array}{l}\text { 1st-ash after } \\
\text { no. } 3\end{array}$ & $\begin{array}{l}\text { 2nd-fresh } \\
\text { ash }\end{array}$ & fresh ash & $\begin{array}{l}\text { 1st-ash } \\
\text { after no. } 5\end{array}$ & 2nd-fresh ash \\
\hline Humid ash mass & $\mathrm{kg}$ & 7.1 & 7.2 & 6.5 & 6.5 & 6.2 & 8.1 & 8.1 & 6.3 \\
\hline L/S (liquid /solid) & - & 0.42 & 0.31 & 0.43 & nd & 0.25 & 0.34 & nd & $0.12^{1)}$ \\
\hline Ambient temp & ${ }^{\circ} \mathrm{C}$ & 21 & 21 & 15 & 16 & 16 & 19 & 17 & 17 \\
\hline Peak temp ash bed & ${ }^{\circ} \mathrm{C}$ & 28 & 24 & 28 & 18 & 28 & 25 & 18 & 23 \\
\hline Gas flow inlet & $\begin{array}{l}\mathrm{dm}^{3} / \mathrm{h} / \mathrm{kg} \\
\mathrm{ash}^{2)}\end{array}$ & 2.0 & 2.0 & 3.7 & 3.9 & 3.9 & 2.0 & 1.7 & 2.0 \\
\hline $\begin{array}{l}\text { Time until } \\
\text { break-through }\end{array}$ & $\mathrm{h}$ & 80 & 5 & 35 & 5 & 50 & 53 & 4 & 59 \\
\hline $\begin{array}{l}\text { Uptake until } \\
\text { break-through }\end{array}$ & $\begin{array}{l}\mathrm{g} \quad \mathrm{CO}_{2} / \mathrm{g} \\
\text { dry ash }\end{array}$ & 0.15 & - & 0.12 & nd & 0.11 & 0.10 & nd & 0.06 \\
\hline Total time & $\mathrm{h}$ & 101 & 28 & 41 & 60 & 60 & 56 & 72 & 72 \\
\hline Uptake total & $\begin{array}{l}\mathrm{g} \quad \mathrm{CO}_{2} / \mathrm{g} \\
\text { dry ash }\end{array}$ & 0.17 & 0.05 & 0.13 & 0.07 & 0.12 & 0.11 & 0.03 & 0.07 \\
\hline $\mathrm{CH}_{4}$ mean $^{3)}$ & $\%$ & 95.7 & nd & 99.2 & nd & 99.2 & 99.7 & nd & 98.3 \\
\hline $\mathrm{CH}_{4} \max$ & $\%$ & $97.0^{4)}$ & $94.9^{5)}$ & $99.5^{4)}$ & $91.0^{5)}$ & $99.6^{4)}$ & $98.6^{4)}$ & $98.0^{5)}$ & $98.9^{4)}$ \\
\hline
\end{tabular}

${ }^{1)}$ No extra water added, ${ }^{2)}$ Flow adjusted to $20{ }^{\circ} \mathrm{C}$ and 1 atm, ${ }^{3)}$ Mean until breakthrough of $\mathrm{CO}_{2} ;{ }^{4)}$ mean of three highest values, ${ }^{5)}$ highest value, $\mathrm{nd}=$ not determined

The particle size distribution (Figure 2) shows that both ashes predominantly had particle sizes $<0.4 \mathrm{~mm}$. The WCA contained mostly fine particles with $65 \%$ by mass $<0.1 \mathrm{~mm}$, reflecting the fact that fly ash was included.

\subsection{Carbonation Experiments}

\subsubsection{WPA 1-Step Experiments}

In experiment no. $1, \mathrm{CO}_{2}$ was not detected in the outlet gas during the first $80 \mathrm{~h}$ of operation (Figure $3 \mathrm{a}$ ). The $\mathrm{CH}_{4}$ concentration increased rapidly from the very beginning of the experiment and after $8 \mathrm{~h}$ it reached approx. $96 \%$. This was maintained until the breakthrough of $\mathrm{CO}_{2}$, i.e. when reaching $>1 \% \mathrm{CO}_{2}$ in the outlet gas. After $\mathrm{CO}_{2}$ breakthrough the $\mathrm{CO}_{2}$ concentration increased to $20 \%$, concurrent with a decrease in $\mathrm{CH}_{4}$ concentration to $76 \%$. The experiment was terminated after 101 hours. During the experiment approx. $0.8 \% \mathrm{O}_{2}$ was detected in the outlet gas, indicating air leaking into the system. The presence of air in the outlet gas explains why the $\mathrm{CH}_{4}$ concentration only reached $96 \%$ on average, even though the $\mathrm{CO}_{2}$ concentration was $0 \%$. Furthermore, the exothermic carbonation process led to an increased temperature in the ash bed where temperature was up to $7{ }^{\circ} \mathrm{C}$ higher than the ambient temperature during experiment no.1 (Table 1). Experiment no. 2 (a second treatment 
after mixing the ash from reactor no. 1) reached a $\mathrm{CH}_{4}$ peak of $95 \%$ after $5 \mathrm{~h}$, at which time $\mathrm{CO}_{2}$ breakthrough was observed. The results from experiment no. 3 showed the same gas concentration pattern as in experiment no. 1. However, the $\mathrm{CO}_{2}$ uptake was slightly lower for experiment no. 3 and the $\mathrm{CO}_{2}$ breakthrough occurred earlier (after $35 \mathrm{~h}$ ) because of the higher specific inlet gas flow.

Table 2. The composition and characteristics of the ashes studied. LOI = loss on ignition

\begin{tabular}{llll}
\hline & & WPA & WCA \\
\hline Density & $\mathrm{kg} / \mathrm{dm}^{3}$ & 0.43 & 0.50 \\
$\mathrm{TS}$ & \% & 99.5 & 89.4 \\
$\mathrm{LOI} 1000{ }^{\circ} \mathrm{C}$ & \% of TS & 14.2 & 30.4 \\
$\mathrm{SiO}_{2}$ & \% of TS & 7.8 & 7.9 \\
$\mathrm{Al}_{2} \mathrm{O}_{3}$ & \% of TS & 1.5 & 1.2 \\
$\mathrm{CaO}$ & \% of TS & 36.0 & 31.2 \\
$\mathrm{Fe}_{2} \mathrm{O}_{3}$ & \% of TS & 2.1 & 0.6 \\
$\mathrm{~K}_{2} \mathrm{O}$ & \% of TS & 10.1 & 14.1 \\
$\mathrm{MgO}$ & \% of TS & 8.5 & 7.0 \\
$\mathrm{MnO}$ & \% of TS & 3.5 & 1.9 \\
$\mathrm{Na}_{2} \mathrm{O}$ & \% of TS & 0.5 & 0.3 \\
$\mathrm{P}_{2} \mathrm{O}_{5}$ & \% of TS & 3.5 & 2.8 \\
$\mathrm{TiO}_{2}$ & \% of TS & 0.00 & 0.04 \\
\hline
\end{tabular}

Experiment no. 1 showed the highest uptake with $0.15 \mathrm{~g} \mathrm{CO}_{2} / \mathrm{g}$ dry ash until $\mathrm{CO}_{2}$ breakthrough, and the uptake increased further to $0.17 \mathrm{~g} \mathrm{CO}_{2} / \mathrm{g}$ dry ash at termination of the experiment (Table 1). Experiment no. 2 showed an uptake of $0.05 \mathrm{~g} \mathrm{CO}_{2} / \mathrm{g}$ dry ash, which resulted in a total uptake of $0.22 \mathrm{~g} \mathrm{CO}_{2} / \mathrm{g}$ dry ash after both experiments.

\subsubsection{WPA 2-Step Experiments}

The results from experiment no. 2 showed that there is remaining potential to capture $\mathrm{CO}_{2}$ after the first treatment. Therefore, a 2-step experimental set up was performed (experiment no.4), where the ash after termination of experiment no. 3 was used as the first reactor (4A), while the second reactor (4B) was loaded with fresh ash. The $\mathrm{CO}_{2}$ breakthrough in reactor $4 \mathrm{~A}$ occurred after $5 \mathrm{~h}$ and thereafter the $\mathrm{CO}_{2}$ concentration increased to approx. $30 \%$ (Figure 3b). The $\mathrm{CH}_{4}$ concentration reached approx. $91 \%$, but after $5 \mathrm{~h}$ the $\mathrm{CH}_{4}$ concentration gradually decreased to approx. $65 \%$ as the $\mathrm{CO}_{2}$ concentration increased up to ca $30 \%$ (Figure $3 \mathrm{~b}$ ). In ash reactor $4 \mathrm{~B}$, the $\mathrm{CH}_{4}$ concentration reached $95 \%$ after 5 hours and thereafter the average $\mathrm{CH}_{4}$ concentration was $99 \%$ until $\mathrm{CO}_{2}$ breakthrough occurred after $50 \mathrm{~h}$ of operation. After $60 \mathrm{~h}$, the $\mathrm{CH}_{4}$ and $\mathrm{CO}_{2}$ concentration reached the same level ( $65 \%$ and $30 \%$ respectively) in both ash reactors.

The uptake in reactor $4 \mathrm{~A}$ was $0.07 \mathrm{~g} \mathrm{CO}_{2} / \mathrm{g}$ dry ash, which together with the uptake in experiment no. 3 is $0.20 \mathrm{~g}$ $\mathrm{CO}_{2} / \mathrm{g}$ dry ash for that ash batch. The fresh ash in reactor $4 \mathrm{~B}$ reached $0.12 \mathrm{~g} \mathrm{CO}_{2} / \mathrm{g}$ dry ash, which was lower compared with experiment no. 1 and no. 3 (Table 1). After experiment no. 4 was terminated, the ash in reactor 4B was analysed for water content and the results showed that it had decreased from the initial $20 \%$ to $14 \%$. This decrease due to evaporation could have been a limiting factor in the carbonation process.

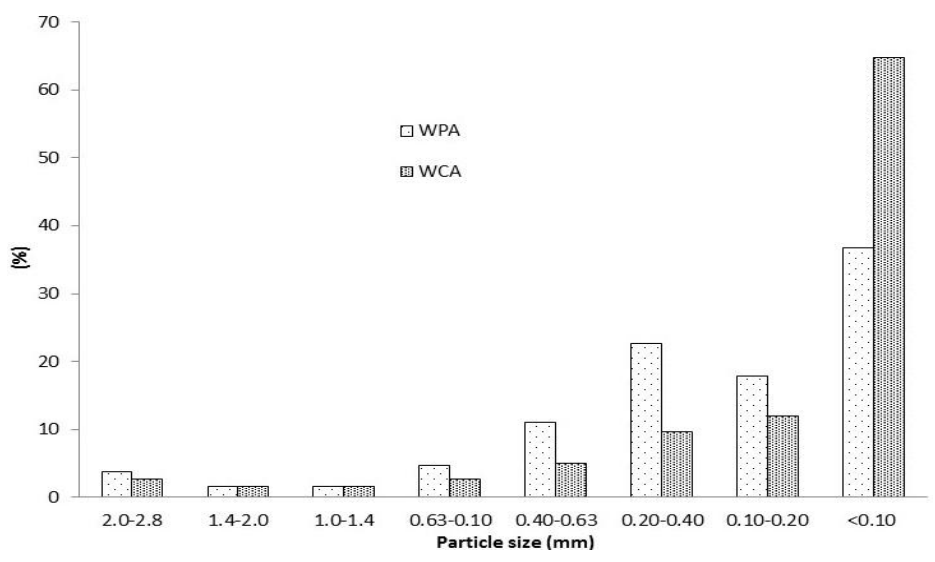

Figure 2. Particle size distribution for dry ash, WCA= wood chip ash, WPA= Wood pellet ash. 
(a)

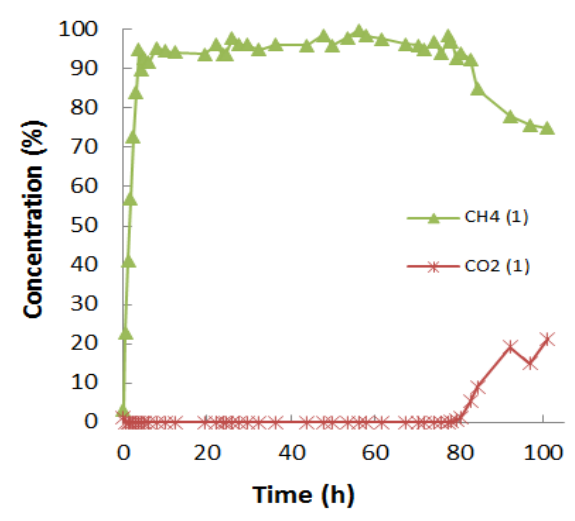

(c)

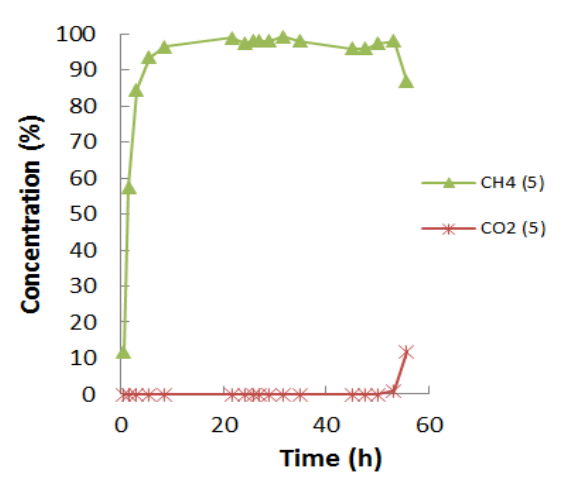

(b)

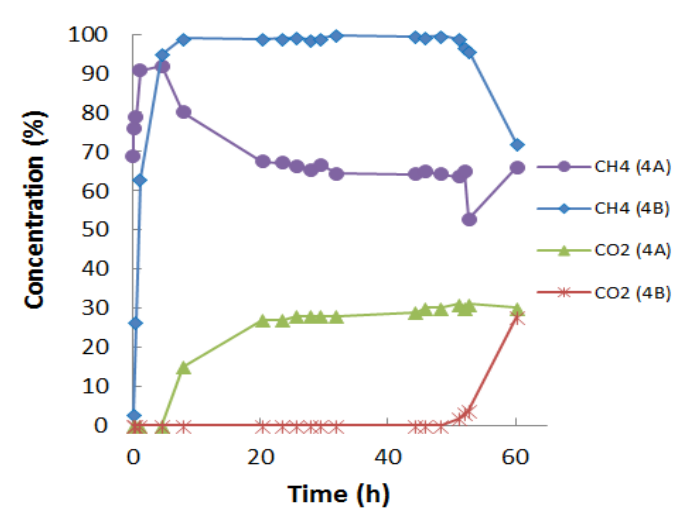

(d)

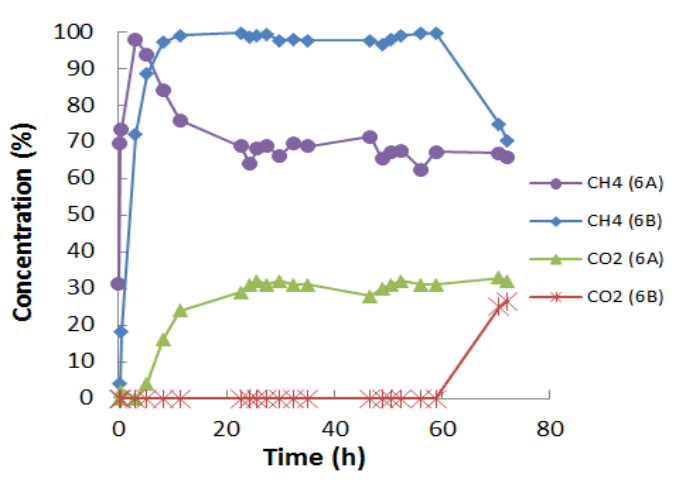

Figure 3. The concentration of $\mathrm{CH}_{4}$ and $\mathrm{CO}_{2}$ in the outlet gas from the ash reactors. (a) 1-step experiment with WPA (no. 1), (b) 2-step experiment with WPA(no. 4A and 4B), (c) 1-step experiment with WCA(no. 5) and (d) 2-step experiment with WCA(no. 6A and 6B)

\subsubsection{WCA 1-Step Experiment}

The 1-step experiment with WCA(experiment no. 5) was performed at the same specific gas flow and a slightly lower L/S-ratio compared to experiment no. 1 with WPA(Table 1). The $\mathrm{CH}_{4}$ concentration increased rapidly and remained at an average of $98 \%$ for $53 \mathrm{~h}$ until $\mathrm{CO}_{2}$ breakthrough (Figure 3c). The uptake of $\mathrm{CO}_{2}$ until breakthrough was $0.10 \mathrm{~g} \mathrm{CO}_{2} / \mathrm{g}$ dry ash (Table 1). After $56 \mathrm{~h}$ the experiment was terminated and that time the $\mathrm{CO}_{2}$ and $\mathrm{CH}_{4}$ concentrations were $12 \%$ and $87 \%$ respectively. The total uptake of $\mathrm{CO}_{2}$ for experiment no. 5 was $0.11 \mathrm{~g} \mathrm{CO}_{2} / \mathrm{g}$ dry ash.

\subsubsection{WCA2-Step Experiment}

The ash reactor after experiment no. 5 was used as the first step (reactor 6A) with a serial connection to an ash reactor with fresh WCA (reactor 6B) in experiment no. 6 (Table 1). The moisture level was not adjusted in the fresh WCA ash, which means that the L/S-ratio was only 0.12 . The $\mathrm{CO}_{2}$ breakthrough in ash reactor 6A occurred after 4 hours and then the $\mathrm{CO}_{2}$ concentration gradually increased and levelled off at approx. $30 \%$ (Figure $3 \mathrm{~d}$ ). The $\mathrm{CH}_{4}$ concentration in ash reactor $6 \mathrm{~A}$ peaked at $98 \%$ after 3 hours before gradually decreasing and levelling off at $65-70 \%$. In ash reactor $6 \mathrm{~B}, \mathrm{CO}_{2}$ was not detected in the outlet gas until after $59 \mathrm{~h}$ and the $\mathrm{CH}_{4}$ concentration averaged $98 \%$ before $\mathrm{CO}_{2}$ breakthrough. After $72 \mathrm{~h}$ the experiment was terminated and at that time the $\mathrm{CO}_{2}$ and $\mathrm{CH}_{4}$ concentrations were $27 \%$ and $71 \%$ respectively.

The uptake of $\mathrm{CO}_{2}$ in ash reactor $6 \mathrm{~A}$ reached $0.031 \mathrm{~g} \mathrm{CO}_{2} / \mathrm{g}$ dry ash and together with the previous experiment (no. 5) the total uptake was $0.14 \mathrm{~g} \mathrm{CO}_{2} / \mathrm{g}$ dry ash. The uptake in reactor $6 \mathrm{~B}$ was only $0.074 \mathrm{~g} \mathrm{CO}_{2} / \mathrm{g}$ dry ash, which was lower compared to experiment no. 5 and could likely be a result of the low L/S-ratio in the ash.

\subsection{Titration}

The fresh WPA and WCA both had high pH (WPA: 13.0 \pm 0.3 ; WCA: 12.9 \pm 0.7 ). Carbonation causes the release 
of hydrogen ions, which explains why the $\mathrm{pH}$ of the carbonised ash was 2-3 units lower when compared to the fresh ash.

The titration curves for the WPA (experiment no. 1 and no. 2) and WCA (experiment no. 5) before and after carbonation are presented in Figure 4. The fresh WPA initially showed good buffering capacity at around $\mathrm{pH} 12$ due to a high concentration of hydroxide ions. The small buffering action, which occurred at $\mathrm{pH} 8.5$ indicated the presence of $\mathrm{CaCO}_{3}$ buffers in the solution. However, the dissolution of $\mathrm{CaCO}_{3}$ is slow at high $\mathrm{pH}(>7)$, and therefore $\mathrm{pH}$ dropped rapidly to 5-6 with the continued addition of acid. Around this $\mathrm{pH}$, the dissolution of $\mathrm{Ca}$ was more efficient, which explains the ash buffering properties. The decrease in buffering capacity after $\mathrm{pH} 4.5$ indicates that all the $\mathrm{CaCO}_{3}$ in the sample can be considered dissolved (Figure 4).

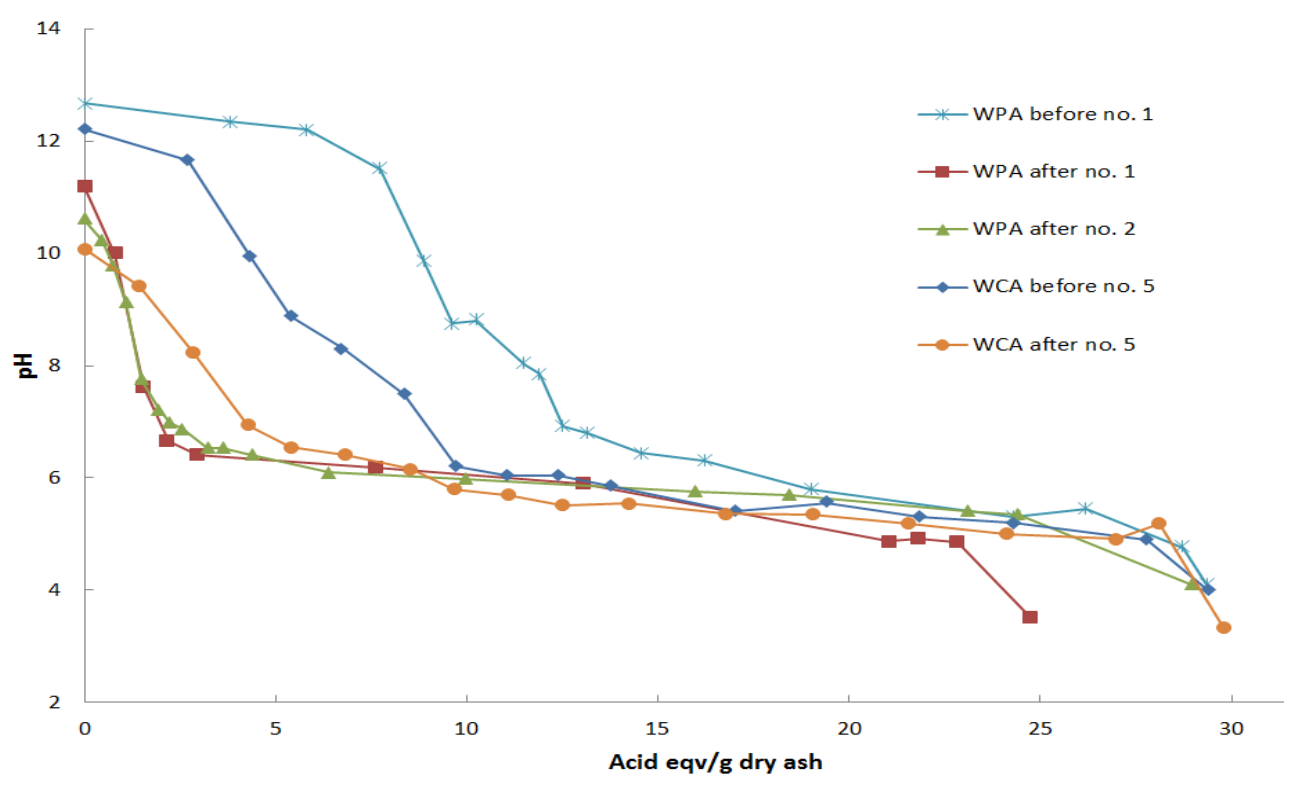

Figure 4. Titration curves for WPA and WCA before and after the experiments.

During the carbonation process hydroxide ions are consumed leading to decreased $\mathrm{pH}$ in the ash. Before titration of the carbonised WPA pH was approx. 11. The carbonised WPA shows limited buffering capacity at $\mathrm{pH} 10-11$ due to the lack of hydroxide ions and thus the $\mathrm{pH}$ drops rapidly to 5-6. Buffering capacity around $\mathrm{pH} 6$ is considerably higher for carbonised WPA compared to the fresh WPA, which is expected given that the carbonised ash contains more $\mathrm{CaCO}_{3}$ than the fresh ash. Titration of the carbonised WPA in experiment no. 2 (treated twice with mixing in between) showed higher buffering capacity than the carbonised WPA from experiment no. 1 (Figure 4).

Titration of WCA showed a similar pattern to the WPA. However, while the fresh WCA did not have a high buffering capacity at $\mathrm{pH} 12$, it buffered effectively around $\mathrm{pH} 6$ (Figure 4). This indicates that the WCA has a relative high percentage of $\mathrm{CaCO}_{3}$ before carbonation compared to WPA. The carbonised WCA showed a slightly higher buffering capacity between $\mathrm{pH}$ 6-10 compared to carbonised WPA. This can likely be explained by the smaller ash particle size distribution of the WCA, which results in a faster dissolution of minerals during titration. The carbonised WCA has a high buffering capacity around $\mathrm{pH} 6$, indicating a high content of $\mathrm{CaCO}_{3}$ in the ash.

\section{Discussion}

The results from this study show that $\mathrm{Ca}$ rich wood ashes have very good $\mathrm{CO}_{2}$ uptake capacity, which is in accordance with the findings of Chavez \& Guadarrama (2015). The uptake was slightly higher in the WPA compared to WCA, which can be explained by its higher content of free $\mathrm{CaO}$. Since the WCA was exposed to moisture during storage it is likely that some of the free $\mathrm{CaO}$ in the WCA was carbonised before the tests began. This is also in accordance with the results from del Valle-Zermeño et al. (2015), who showed that weathered MSWI bottom ash had a lower $\mathrm{CO}_{2}$ uptake capacity than fresh MSWI bottom ash. The titration tests performed in our study confirmed that fresh WCA had a higher carbonate buffering capacity compare to fresh WPA. 
However, even if the WCA was exposed to moisture long before the tests started, the ash still showed a considerable uptake of $\mathrm{CO}_{2}$ during the tests.

The highest uptake was achieved by the WPA, $0.17 \mathrm{~g} \mathrm{CO}_{2} / \mathrm{g}$ dry ash after the 1-step experiment and $0.20 \mathrm{~g}$ $\mathrm{CO}_{2} / \mathrm{g}$ dry ash after the 2-step experiment. This can be compared with the reported uptake capacity of MSWI bottom ash; ranging from ca 0.01 to $0.02 \mathrm{~g} \mathrm{CO}_{2} / \mathrm{g}$ bottom ash with a water content of $17.5 \%$ to $22.3 \%$ (Mosbauer et al., 2014), and $0.03-0.05 \mathrm{~g} \mathrm{CO}_{2} / \mathrm{g}$ dry bottom ash (del Valle-Zermeño et al., 2015). As such, the ashes from combustion of wood pellets or wood chips clearly have a much higher $\mathrm{CO}_{2}$ uptake capacity compared to the bottom ash from MSWI tested in other studies. The particle size fractionation showed a high degree of very fine particles in both WPA and WCA. This results in a high specific surface area, which is favourable for the carbonation process. Bottom ashes from MSWI usually have coarser particle size distribution compared to wood ashes used in this study (Mosbauer et al., 2014; del Valle-Zermeño et al., 2015) and this fact together with the difference in $\mathrm{Ca}$ content explains why the $\mathrm{CO}_{2}$ capturing performance is much higher for the studied wood ashes compared to MSWI bottom ash.

The high degree of fine particles in WPA and WCA could be suspected to result in a high pressure drop over the ash bed. Howe ver, pressure drop was low during all experiments; approx. $100 \mathrm{~Pa}(1 \mathrm{mBar})$ during the 1 -step experiments and 200-300 $\mathrm{Pa}$ during the 2-step experiments, at an ash bed height of $0.2 \mathrm{~m}$ per reactor. The pressure drop when using a higher ash bed should be tested in the future to explore possible consequences at commercial scale. Nevertheless, the very low pressure drop reported in this study indicates that the system pressure in an anaerobic digester (normally 10-40 mbar) should be sufficient to force the biogas through the ash bed. Furthermore, the upgraded gas leaving the ash reactor is close to atmospheric pressure and saturated with water. Therefore the gas needs to be dried, odourised and pressurised before it can be used in vehicles or injected to the gas grid.

The uptake capacity of $\mathrm{CO}_{2}$ until the time of breakthrough was higher for WPA at an inlet gas flow rate of 2 $\mathrm{dm}^{3} / \mathrm{h} / \mathrm{kg}$ ash compared to 3.7 and $3.9 \mathrm{dm}^{3} / \mathrm{h} / \mathrm{kg}$ ash (Table 1). This indicates that gas flow rate has an impact on $\mathrm{CO}_{2}$ uptake capacity. However, the impact of the gas flow rate and possible limitations should be explored with a systematic approach in future studies because this will impact the sizing of the ash bed in relation to the operation time and frequency of ash bed replacement. Furthermore, it was noticed that the temperature rise in the ash bed showed a correlation to an increased inlet gas flow. This can be expected since the carbonation process is exothermic and a higher inlet flow of $\mathrm{CO}_{2}$ results in greater heat release. However, the peak temperature in the ash bed ne ver reached over $30^{\circ} \mathrm{C}$ in this study (ambient temperature $15-21^{\circ} \mathrm{C}$ ), while it has been reported that temperatures of up to $60{ }^{\circ} \mathrm{C}$ have been obtained due to carbonation (Mostbauer et al., 2008). A relatively low peak temperature will reduce water evaporation from the ash bed, thus maintaining better conditions for solution of $\mathrm{CO}_{2}$ in the water phase with subsequent carbonation. In addition, reduced evaporation from the ash bed will also be beneficial for drying the upgraded biogas where less water needs to be removed to reach the appropriate dew point set by the vehicle fuel standard.

The outlet gas from the ash reactor contained more or less pure $\mathrm{CH}_{4}$ saturated with water. For experiment no. 1 there were minor problems with leakage in the system which gave rise to air being detected in the outlet gas. That is the reason why the $\mathrm{CH}_{4}$ concentration in experiment no. 1 only reached $97 \%$ at its peak, even though the $\mathrm{CO}_{2}$ concentration was $0 \%$ at that time.

Overall, this study showed that $\mathrm{Ca}$ rich wood ash can be used for upgrading biogas to vehicle fuel quality (97\% $\mathrm{CH}_{4}$ ). However, a small scale biogas plant producing biogas corresponding to $1 \mathrm{GWh}(3.6 \mathrm{TJ})$ annually would need 650 tonnes of dry ash per year to upgrade all of the biogas to vehicle fuel quality. This calculation is based on wood ash with an uptake performance of $0.20 \mathrm{~g} \mathrm{CO}_{2} / \mathrm{g}$ dry ash and an inlet digester gas composition of $60 \%$ $\mathrm{CH}_{4}$ and $40 \% \mathrm{CO}_{2}$. Even if the uptake capacity of the ash is relatively high compared to MSWI bottom ash, the demand of ash is still significant. Nevertheless, there are several Swedish CHP plants producing more than 1,000 tonnes of wood ash annually and with the right local conditions upgrading with wood ash could be a suitable solution for small scale upgrading. For future studies, biogas containing trace gases such as hydrogen sulphide and siloxanes should be tested and evaluated regarding the uptake capacity. Furthermore, development of efficient systems for handling and management of ash will be important for the techno-economic performance of this biogas upgrading concept.

A further perspective of using wood fuel ash for biogas upgrading is that increasing demand for wood fuels is causing more biomass to be taken during harvest. As such, there is a need to balance the inputs and outputs of nutrients to ensure sustainable forest management. This can be achieved by returning wood ash to forest land, which also could counteract forest soil acidification (Örlander \& Wickström, 2001; Ingerslev et al., 2001). As the 
ash contains reactive oxides and soluble salts (Ohlsson, 2000) there is a risk that land application could cause negative effects on the vegetation caused by increased $\mathrm{pH}$ (Steenari \& Lindqvist, 1997). Carbonation of the ash is suggested to counteract these negative effects and Egnell et al. (1998) reported that carbonation of applied ash leads to a reduced $\mathrm{pH}$ increase in the O-horizon (forest floor). Therefore, the use of wood fuel ash for biogas upgrading based on accelerated carbonation has the potential to generate two useful products, upgraded biogas of vehicle fuel quality, and stabilized wood ash with a decreased $\mathrm{pH}$ suitable for recycling to forestry.

\section{Conclusions}

The use of Ca rich ash from wood pellets and wood chips for biogas upgrading showed a high $\mathrm{CO}_{2}$ uptake capacity after moisture adjustment of the ash. Wood pellet ash had the highest uptake capacity with $0.20 \mathrm{~g} \mathrm{CO}_{2} / \mathrm{g}$ dry ash, which is 4-8 times higher when compared to studies using municipal solid waste incineration ash. The ash bed managed to remove all of the $\mathrm{CO}_{2}$ in the inlet gas $\left(65 \% \mathrm{CH}_{4}\right.$ and $\left.35 \% \mathrm{CO}_{2}\right)$, resulting in a $\mathrm{CH}_{4}$ concentration of up to $99.6 \%$ in the outlet gas; until the time of $\mathrm{CO}_{2}$ breakthrough in the ash bed. Thus, it was concluded that vehicle fuel quality could be reached. Furthermore, it was concluded that using two reactors in serial is an efficient operation strategy to utilize the total $\mathrm{CO}_{2}$ uptake capacity of the ash, and that the $\mathrm{pH}$ of the ash (approx. 13) was reduced by 2-3 units due to accelerated carbonation. The required volume of ash for the upgrading process is high and therefore this method is probably most suitable for small scale upgrading. Based on the results, upgrading of $1 \mathrm{GWh}(3.6 \mathrm{TJ})$ biogas per year would require approx. 650 tonnes of dry wood ash per year with an uptake of $0.2 \mathrm{~g} \mathrm{CO}_{2} / \mathrm{g}$ dry ash and an inlet biogas composition of $60 \% \mathrm{CH}_{4}$ and $40 \% \mathrm{CO}_{2}$.

\section{Acknowledgments}

This work was supported by the Swedish Farmers' Foundation for Agricultural Research under Grant H1040207. The authors would like to thank Sala Heby Energi and SLU Egendom for supplying ash to the experiments.

\section{References}

Awe, O. W., Zhao, Y., Nzihou, A., Minh, D. P., \& Lyczko, N. (2017). A Review of Biogas Utilisation, Purification and Upgrading Technologies. Waste and Biomass Valorization, 8, 267-283. https://doi.org/10.1007/s12649-016-9826-41

Baciocchi, R., Carnevale, E., Corti, A., Costa, G., Lombardi, L., Olivieri, T., Zanchi, L., \& Zingaretti, D. (2013a). Innovative processes for biogas upgrading with $\mathrm{CO}_{2}$ storage: Results from pilot plant operation. Biomass and Bioenergy, 53,128-137. https://doi.org/10.1016.biombioe.2012.11.016

Baciocchi, R., Carnevale, E., Costa, G., Gavascia, R., Lombardi, L., Olivieri, T., Zanchi, L., \& Zingaretti, D. (2013b). Performance of a biogas upgrading process based on alkali absorption with regeneration using air pollution control residues. Waste Management, 33, 2694-2705. https://doi.org/10.1016/j.wasman.2013.08.022

Bauer, F., Persson, T., Hulteberg, C., \& Tamm, D. (2013). Biogas upgrading - technology overview, comparison and perspectives for the future. Biofuels Bioproducts \& Biorefining, 7, 499-511. https://doi.org/10.1002/bbb.1423

Börjesson, P., Tufvesson, L., \& Lantz, M. (2010). Livscykelanalys av svenska biodrivmedel. [Life cycle assessment of Swedish biofuels]. Environmental and Energy Systems Studies, Report no 70. Lund University, Sweden. Retrieved from http://www.miljo.lth.se/svenska/internt/publikationer_internt/pdf-filer/rapport\%2070.pdf

Chavez, R. H., \& Guadarrama, J. J. (2015). Biogas treatment by ashes from incineration processes. Clean Technologies and Environmental Policy, 17, 1291-1300. https://doi.org/10.1007/s10098-015-0980-3

del Valle-Zermeño, R., Romero-Güiza, M. S., Chimenos, J. M., Formosa, J., Mata-Alvarez, J., \& Astals, S. (2015). Biogas upgrading using MSWI bottom ash: An integrated municipal solid waste management. Renewable Energy, 80,184-189. https://doi.org/10.1016/j.renene.2015.02.006

Egnell, G., Nohrstedt, H. Ö., Westling, O., \& Örlander, G. (1998). Miljökonsekvensbeskrivning (MKB) av skogsbränsleuttag, asktillförsel och övrig näringskompensation. [Environmental impact assessment (EIA) of forest fuel extraction, ash application and other nutrient compensation measures]. Swedish Forest Agency Report 1, Stockholm, Sweden.

Ingerslev, M., Mälkönen, E., Nielsen, P., Nohrstedt H. Ö., Ostendorf, D. W., \& Raulund-Rasmussen, K. (2001). Main findings and future challenges in forest nutritional research and management in the Nordic countries. Scandinavian Journal of Forestry Research, 6, 488-501. https://doi.org/10.1080/02827580152699330 
Jarvis, Å., Nordberg, A., Mathisen, B., \& Svensson, B. H. (1995). Stimulation of conversion rates and bacterial activity in a silage-fed two-phase biogas process by initiating liquid recirculation. Antonie Van Leeuwenhoek Journal of Microbiology, 68, 317-327.

Kimming, M., Sundberg, C., Nordberg, A., Baky, A., Bernesson, S., \& Hansson, P. A (2015). Replacing fossil energy for organic milk production - Potential biomass sources and GHG emission reductions. Journal of Cleaner Production, 106, 400-407. https://doi.org/10.1016/j.jclepro.2014.03.044

Lantz, M. (2012). The economic performance of combined heat and power from biogas produced from manure in Sweden - A comparison of different CHP technologies. Applied Energy, 98, 502-511. https://doi.org/10.1016/j.apenergy.2012.04.015

Lombardi, L., Carnevale, E., Baciocchi, R., \& Costa, G. (2015). Biogas upgrading by a combination of innovative treatments based on carbonation of waste incineration residues. Waste and Biomass Valorization, 6, 791-803. https://doi.org/10.1007/s12649-015-9413-0

Mostbauer, P., Lenz, S., \& Lechner, P. (2008). MSWI bottom ash for upgrading of biogas and landfill gas. Environmental Technology, 29, 757-764. https://doi.org/10.1080/09593330801987061

Mostbauer, P., Lombardi, L., Olivieri, T., \& Lenz, S. (2014). Pilot scale evaluation of the BABIU process Upgrading of landfill gas or biogas with the use of MSWI bottom ash. Waste Management, 34,125-133. https://doi.org/10.1016/j.wasman.2013.09.016

Ohlsson, A. K. E. (2000). Carbonation of wood ash recycled to a forest soil as measured by isotope ratio mass spectrometry. Soil Science Society of America Journal, 64, 2155-2161.

Örlander, G., \& Wickström, H. (2001). Åtgärder mot markförsurning och för ett uthålligt brukande av skogsmark. [Measures to counteract soil acidification and obtain a sustainable forest management]. Skogsstyrelsen Meddelande 4-2001, Stockholm.

SCB (2012) Askori Sverige 2012. [Ashes in Sweden 2012]. Svenska EnergiAskor, Stockholm.

Starr, K., Gabarrell, X., Villalba, G., Talens, L., \& Lombardi, L. (2012). Life cycle assessment of biogas upgrading technologies. Waste Management, 32, 991-999. https://doi.org/10.1016/j.wasman.2011.12.016

Starr, K., Talens Peiro, L., Lombardi, L., Gabarrell, X., \& Villalba, G. (2014). Optimization of environmental benefits of carbon mineralization technologies for biogas upgrading. Journal of Cleaner Production, 76, 32-41.https://doi.org/10.1016/j.clepro.2014.04.039

Steenari, B. M., \& Lindqvist, O. (1997). Stabilisation of biofuel ashes for recycling to forest soil. Biomass and Bioenergy, 2, 39-50.

Strömberg, B., \& Herstad Svärd, S. (2012). Biobränslehandboken 2012. [The Biofuel Handbook 2012]. Värmeforsk Report, A08-819, Stockholm.

Swedish Energy Agency. (2014). Energyin Sweden 2013, ET 2013:29, Eskilstuna, Sweden.

Westerholm, M., Roos, S., \& Schnürer, A. (2010). Syntrophaceticus schinkii gen. nov., sp. nov., an anaerobic, syntrophic acetate-oxidizing bacterium isolated from a mesophilic anaerobic filter. FEMS Microbiology Letters, 309, 100-104. https://doi.org/10.1111/j.1574-6968.2010.02023.x

\section{Copyrights}

Copyright for this article is retained by the author(s), with first publication rights granted to the journal.

This is an open-access article distributed under the terms and conditions of the Creative Commons Attribution license (http://creativecommons.org/licenses/by/4.0/). 